\title{
Analysis of Remote Sensing, Gravity, and Magnetotelluric Data on Geothermal Fields in Ogan Komering Ulu (OKU) District, South Sumatra
}

\begin{tabular}{l}
\hline Received \\
23 June 2020 \\
Revised \\
27 Jule 2020 \\
Accepted for Publication \\
27 August 2020 \\
Published \\
27 August 2020
\end{tabular}

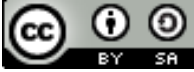

This work is licensed under a Creative Commons AttributionShareAlike 4.0 . International License

\author{
O D Puspita ${ }^{1 *}$, R Juniarto ${ }^{2}$, S S Larasati ${ }^{1}$, H Hamdalah ${ }^{1}$, I Takodama ${ }^{3}$ \\ 1. Department of Geophysics Engineering, Faculty of Mineral Technology, Universitas \\ Pembangunan Nasional "Veteran” Yogyakarta, Jl. SWK 104 Lingkar Utara, Yogyakarta, 55283, \\ Indonesia. \\ 2. Department of Geology Engineering, Faculty of Mineral Technology, Universitas Pembangunan \\ Nasional "Veteran" Yogyakarta, Jl. SWK 104 Lingkar Utara, Yogyakarta, 55283, Indonesia. \\ 3. Center for Coal and Geothermal Mineral Resources, Jl. Soekarno Hatta 444, Bandung, 40254, \\ Indonesia.
}

*Email: oktadpuspita@gmail.com

\section{Introduction}

The use of geothermal energy is estimated to continue to increase in order to meet the demand for electrical energy in Indonesia. Geothermal is an alternative energy that is environmentally friendly to reduce dependence on fossil energy. The largest geothermal energy potential in the world is found in Indonesia, which is around 29,215 MW, or around $40 \%$ of the world's reserves [1]. One area in Indonesia that shows indications of a geothermal energy source is the South Ogan Komering Ulu (OKU) District, South Sumatra. The geothermal indication is characterized by the appearance of several hot springs with temperatures between $40-93{ }^{\circ} \mathrm{C}$ [2]. Geothermal activity in this area is thought to be closely related to the Sumatra fault activity, which resulted in the emergence of volcanic rocks in this area [3].

The stages of geothermal management activities include a preliminary survey, exploration, feasibility study, exploitation and utilization [4]. This research is involved in the preliminary survey stage and geothermal exploration based on geological and geophysical data. The method used in the preliminary survey is a remote sensing method based on the data digital elevation model (DEM) shuttle radar topography mission (SRTM) in order to analyze the straightness formed in the study area. This method can assist in the interpretation of geological structures in the form of faults or fractures, which are weak areas for the path of thermal fluid movement. The gravity method and the magnetotelluric (MT) method are geophysical methods that can be carried out at the geothermal exploration survey stage. The gravity method can determine the density value of subsurface rocks, while the MT method can determine the value of subsurface rock resistivity. 
The results of the two geophysical data can show the existence of geological structures and different types of subsurface rock. The preliminary survey stages and geothermal exploration carried out in this study aims to analyze the presence of geological structures that are indicated as the path of geothermal fluid to the surface and the presence of a geothermal reservoir.

\section{Method}

\subsection{Research Locations and Geology of Research Areas}

The research location is located at local coordinates of X: 10,430-23,386 m and Y: 2,698.4-15,578.9 $\mathrm{m}$, which is included in Ogan Komering Ulu (OKU) South District, South Sumatra (Figure 1). The research area consists of 64 points of gravity and 10 points of MT with lots of $13 \mathrm{~km} \mathrm{x} 13 \mathrm{~km}$ (marked with a black box in Figure 2). The processed data are in the form of secondary data digital elevation map national (DEMNAS), magnetotelluric primary data (MT), which was carried out by field data collection by the Center for Coal and Geothermal Mineral Resources, as well as secondary data for gravity (satellite). Based on elevation data, the southwestern part of the study area is an elevation, which is still included in the Bukit Barisan section on the island of Sumatra.

The island of Sumatra is formed by the confluence of two tectonic plates, namely the IndoAustralian plate, which subducts the Eurasian plate to the north with an average speed of $6 \mathrm{~cm} /$ year [5]. Subduction is the process of meeting two or more tectonic plates that can cause volcanoes to appear. The subduction forms tertiary magmatic activity and controlling volcanism/volcanic activity in Sumatra Island [6]. The tectonic arrangement of the South OKU area is located in the magmatic arc of Sumatra and is right on one of the southern Sumatra fault segments. Lake Ranau, which is located in the south of the study site, is a feature of this tectonic arrangement, where its formation is the result of volcanic processes and tectonism that form a large caldera with pyroclastic material that is widespread around it. Based on the geological map sheet of Baturaja [7] (Figure 2), the rocks on the surface of the research location consist of andesite-basalt volcanic rock units, ranau formations, talangakar formations, gumai formations, and kikim formations. Based on the geological information vertically (cut A - B red line on the map), there are hulusizah formations, bal formations, tarap formations, and igneous intrusions. The research area has four geological structures trending northwest-southeast with a black line marked on the map. This structure is influenced by the presence of a tectonic plate meeting between the IndoAustralian plate (south) and the Eurasian plate (north). Then the meeting of these plates resulted in the emergence of the height along the island of Sumatra, namely the Bukit Barisan. The presence of a portion of the Bukit Barisan area is marked by a dashed line in red on the map.

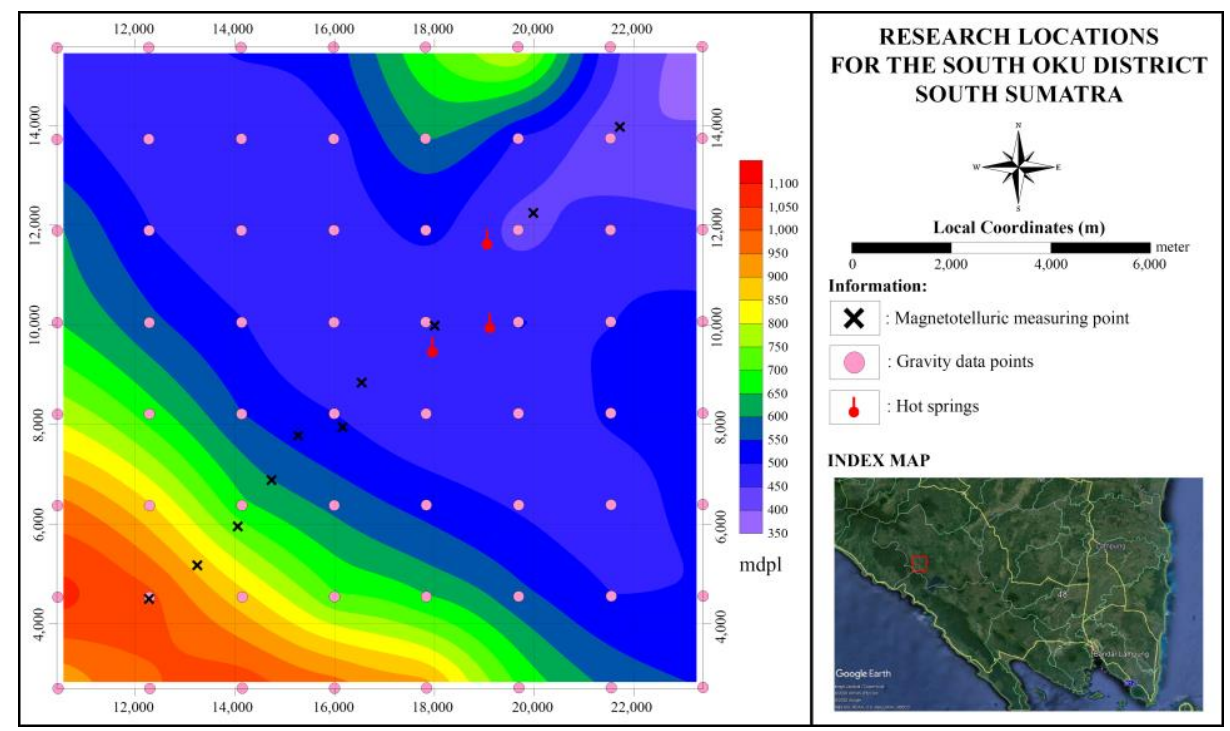

Figure 1. Research sites. 


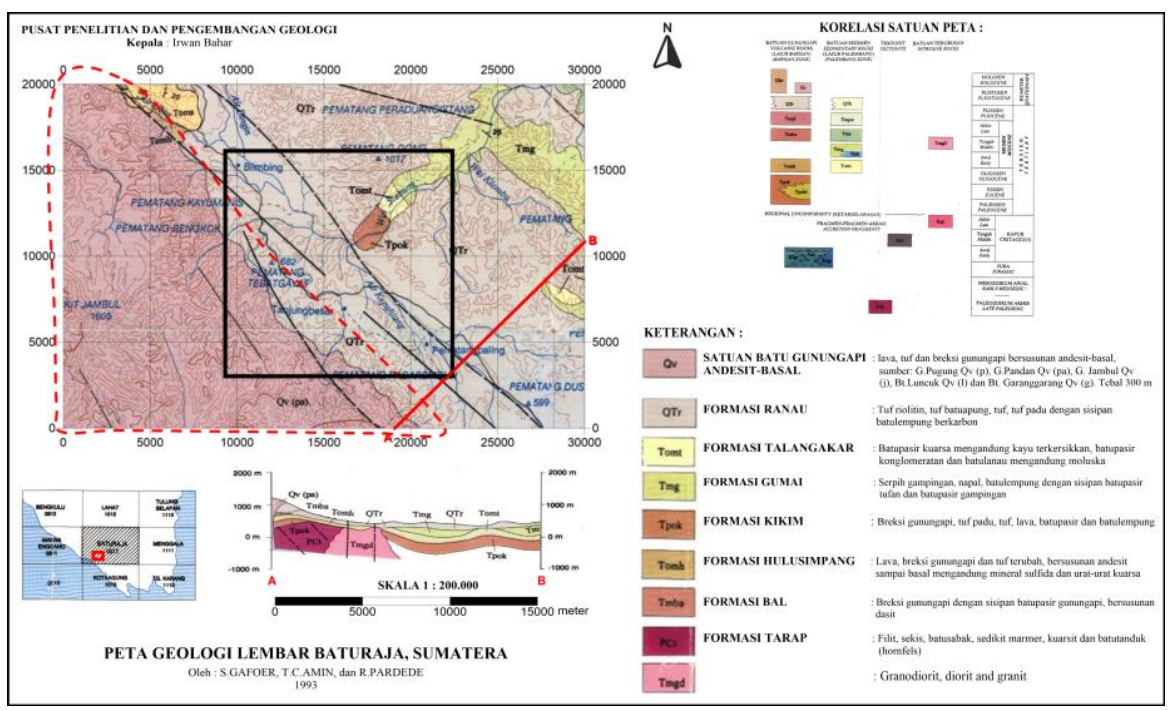

Figure 2. Geological map of the study area.

\subsection{Geological Straightness}

Alignment mapping was assisted by the presence of geomorphological features such as aligned mountains and valleys, sudden changes in ridges, slopes of valleys and rivers, to straight flow patterns [8]. Straightness is one of the features that show weak subsurface elements or structures such as faults [9]. Structural straightness is an alignment that is controlled by geological structures that produce topographic alignments such as ridges and depressions or escarpments. Most of the straightness is a manifestation of the direction of fractures, faults, folds, dykes, and rock layers contact [10].

Interpretation of geological straightness uses DEMNAS data. DEMNAS data processing was carried out using software Global Mapper and ArcGIS to perform a manual lineament draw. Straightness withdrawals were carried out using software Global Mapper by generating straightness data in the form of a single line with the extension .shp (Figure 3). Then the single line was processed using software ArcGIS to tools density map, which produced a straightness density map (Figure 4). This step shows the areas that are most deformed intensively, so it can be estimated that areas with high straightness density values experience tectonic deformation and are most likely close to geological structures. In addition to the straightness density map, the resulting straightness was also used to make rosette diagrams using software Rockwork. Data bearing the result of alignment drawing in Global Mapper is inputted to Rockwork and processed with a rosette diagram. The rosette diagram is useful for seeing the direction of the straightness distribution (Figure 5).

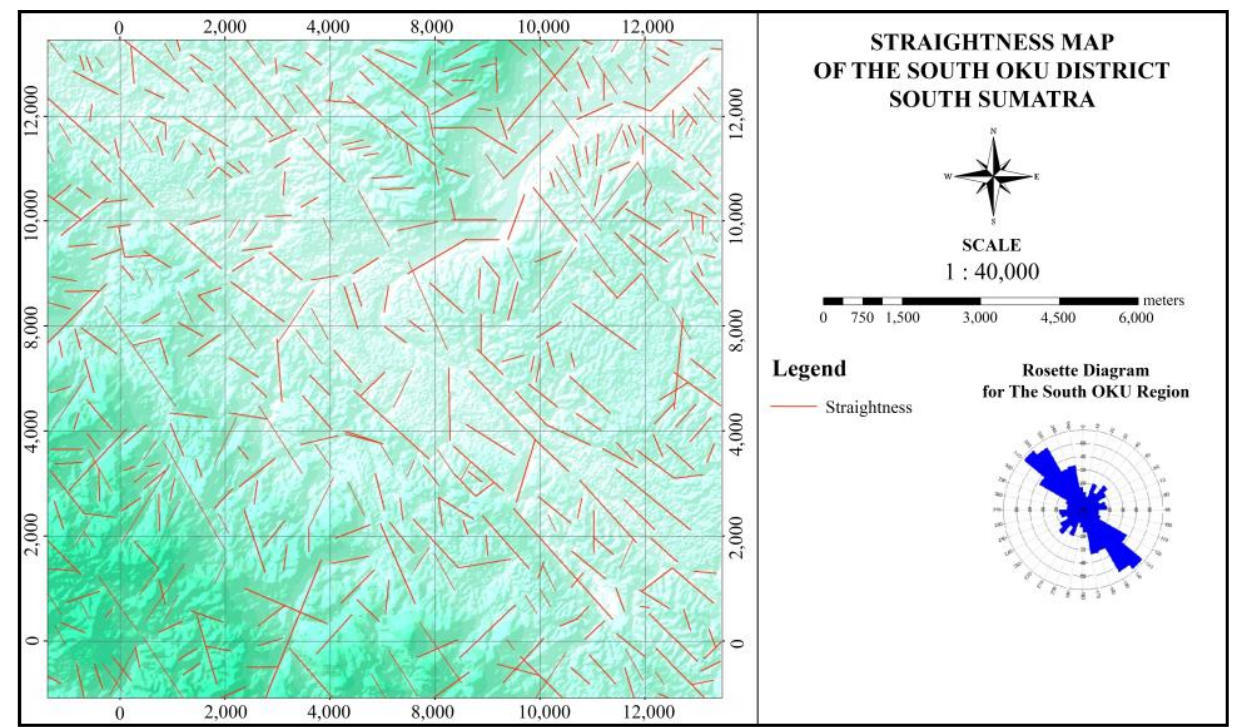

Figure 3. Straightness map. 


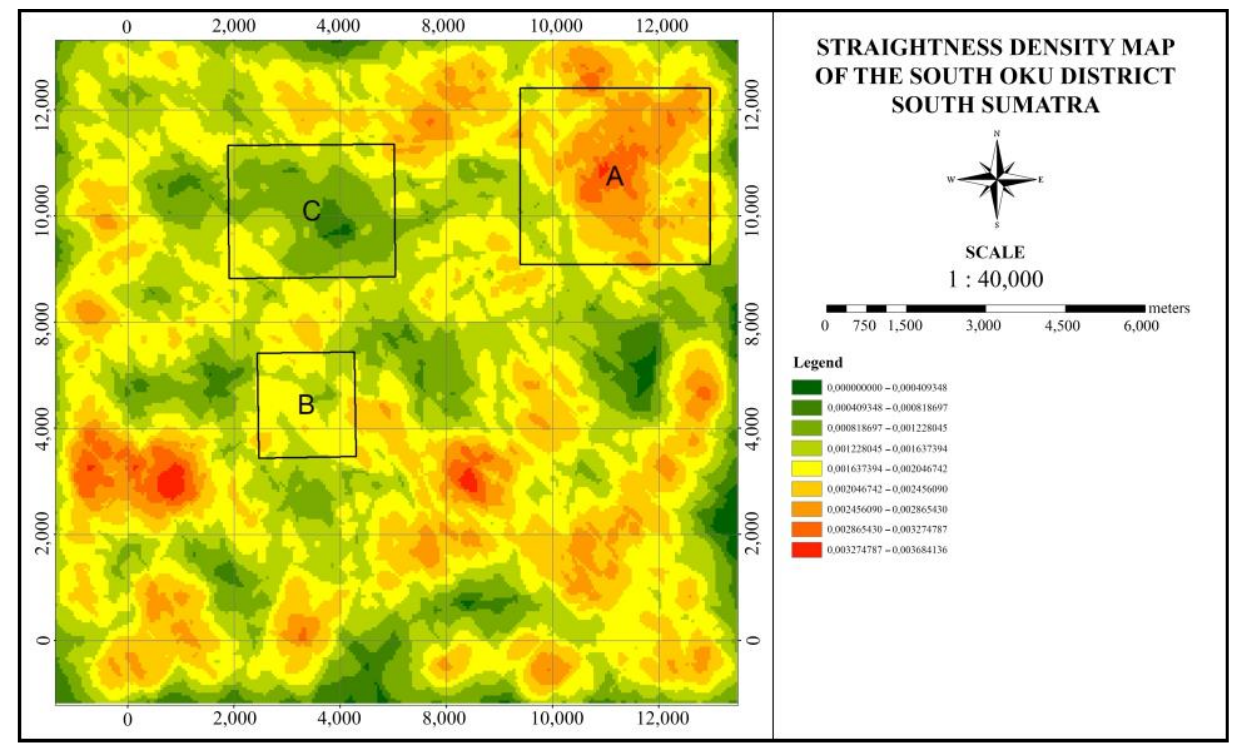

Figure 4. Straightness density map.

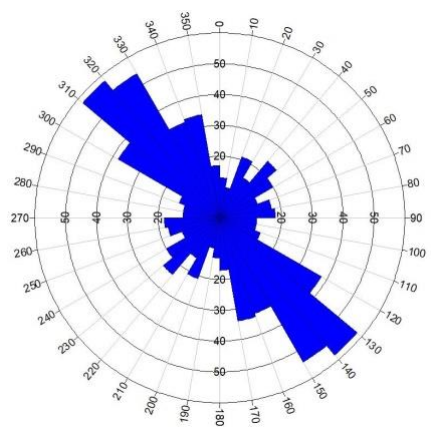

Figure 5. Rosette diagram.

\subsection{Gravity Method}

The basic principle of the gravity method is to measure the variation in the gravitational field caused by the difference in the density of the rocks below the earth's surface [11]. The gravitational method is based on Newton's laws of gravity [12]. Newton's law of gravity states that the attractive force between two objects is proportional to the mass of the two objects and inversely proportional to the distance between the centers of mass of the two objects [13], expressed in mathematical equations

$$
F_{12}=-\mathrm{G} \frac{m_{1} m_{2}}{r^{2}}
$$

where $F_{12}$ is the force experienced by object $\mathrm{m} 1$, and $\mathrm{G}$ is the universal constant of gravity $(6,6732 \mathrm{x}$ $10^{-11} \mathrm{Nm}^{2} / \mathrm{kg}^{2}$ ). This research uses gravity data from satellite observations in the form of the gravitational free air correction (GFAC) value which still needs to be done by Bouguer correction and field correction in order to know the value of the corrected gravitational acceleration anomaly. Mathematically, the corrections are written in equations

$$
\begin{gathered}
A B S=G F A C-B C \\
A B S=G F A C-0,04193 \rho h
\end{gathered}
$$

where ABS is a simple Bouguer anomaly, GFAC is the gravitational acceleration corrected by free air $(\mathrm{mGal}), \mathrm{BC}$ is a Bouguer correction, $\rho$ is a Bouguer density $(\mathrm{gr} / \mathrm{cc})$, and $\mathrm{h}$ is a height $(\mathrm{m})$. After knowing the value of the simple Bouguer anomaly, we can calculate the complete Bouguer anomaly (ABL) using the equation

$$
A B L=A B S+T C
$$

where $\mathrm{ABL}$ is a complete Bouguer anomaly, $\mathrm{ABS}$ is a simple Bouguer anomaly, and $\mathrm{TC}$ is a correction of terrestrial and marine terrain. 


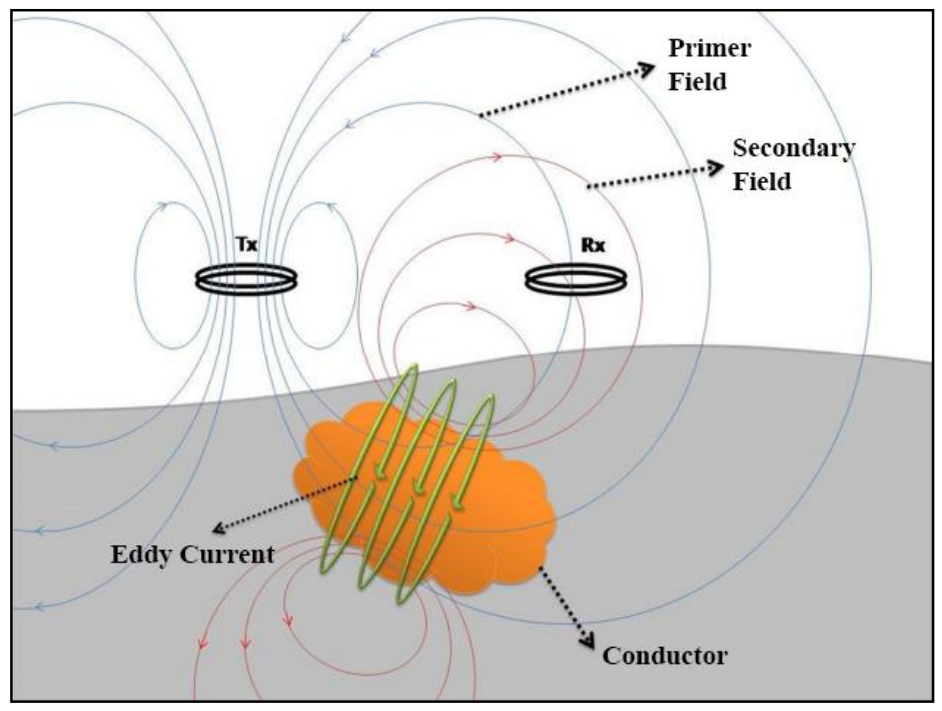

Figure 6. Electromagnetic field induction.

\subsection{Magnetotelluric Method (MT)}

The magnetotelluric method (MT) is a geophysical method that is often used in geothermal exploration. One of the advantages possessed by this method is its penetration, which is quite deep $(>5 \mathrm{~km})$ and more sensitive to the conductive layer under the resistive formation in volcanic environments [14]. The MT method can determine the distribution of rock and subsurface rock layers based on the resistivity value [15]. The working principle of the MT method is to measure passively the components of the electric field $(E)$ and the natural magnetic field $(H)$, which change with time $(t)$. The MT method makes use of natural variations in the electromagnetic field with a frequency range of $10^{-5}-10^{4} \mathrm{~Hz}$ [16]. The MT method refers to Maxwell's law which is the basic law of electricity and magnetism, which is written in equations

$$
\begin{gathered}
\nabla \times E=-\frac{\partial B}{\partial t} \\
\nabla \times H=j+\frac{\partial D}{\partial t} \\
\nabla \cdot D=q \\
\nabla \cdot B=0
\end{gathered}
$$

where $E$ is the electric field (Volt $/ \mathrm{m}), B$ is the flux or magnetic induction (Weber $\left./ \mathrm{m}^{2}\right), H$ is the magnetic field (Ampere/m), $D$ is the electric displacement $\left(\mathrm{Coulomb} / \mathrm{m}^{2}\right)$, and $j$ is the current density (Ampere $/ \mathrm{m}^{2}$ ).

The basic principle of the MT method is that electromagnetic waves are transmitted into the earth $\left(T_{\mathrm{x}}\right)$ interacting with a medium that has a specific resistivity value (Figure 6). When the primary electromagnetic field reaches the earth's surface, the electromagnetic field will induce currents (known as Eddy currents) in the layers of the earth, which are considered conductors [17]. Thus, it caused secondary electromagnetic waves as explained by Ampere's law where the strength of the magnetic field produced depends on the amount of current and the conductivity of the induced medium. The change in the second magnetic field is the value to be recorded by the receiver $\left(R_{\mathrm{x}}\right)$, where the transmitter $\left(T_{\mathrm{x}}\right)$ is a source of electromagnetic waves that has a primary magnetic field $\left(H_{p}\right)$. Then, the wave is transmitted below the earth's surface, which has a certain resistivity value so that a secondary magnetic field $\left(H_{s}\right)$ interaction occurs. The result of the interaction was finally captured by the receiver $\left(R_{\mathrm{x}}\right)[18]$.

MT data obtained in field measurements were processed using software SSMT, MtEditor, and WinGlink. Software SSMT was used for data conversion from the time domain to the frequency domain and robust processing. Software MtEditor was used for selection cross power. At the same time, the WinGlink software was used for making MT 2D inversion. 


\section{Results and Discussion}

\subsection{Geological Straightness Data}

The straightness density map data in South OKU, South Sumatra (Figure 4), is used to interpret permeability in several research areas. A high-density value indicates that the zone has better permeability than the zone that has a lower density. Based on the straightness density analysis carried out, it shows that the yellow to red zone is a zone that has a high straightness density value. The zone is spread across the northeast, southeast, and southwest of the research location. These zones are interpreted as permeable zones that can act as pathways for geothermal fluids because these zones have the ability to absorb water better than the surrounding zone. In addition, based on the rose diagram, it is obtained that the dominant straightness direction is northwest-southeast. Ground checking is needed in this study so that it can prove that zones with high straightness density values are associated with high geological structures in the field.

\subsection{Gravity Data}

The ABL value, which shows the variation in the value of the gravitational acceleration of the subsurface rocks in the South OKU area, South Sumatra, has a range of 15-60 mGal. The variation in the acceleration due to gravity is influenced by variations in the density of rocks beneath the earth's surface. Based on Newton's law of gravity (equation 1), the value of gravitational acceleration is directly proportional to the density of a medium. Then it can be said that the zone which has a high value of gravitational acceleration has a high-density value (density) as well.

Zones with high anomalous values are interpreted as the presence of crystalline rocks. These crystalline rocks can be in the form of igneous or metamorphic rocks because the two rocks have almost the same density, so that they are difficult to distinguish. Zones with low anomaly values are interpreted as the presence of sedimentary or pyroclastic rocks. Both statements are based on the higher density of igneous and metamorphic rocks than the density of sedimentary and pyroclastic rocks [11]. Zones with anomalous contrasts can show a geological structure because the structural zone is a zone of destruction, which causes a significant decrease in the value of the gravitational acceleration.

The line pattern on the ABL map shows a southwest-southeast direction (Figure 7). This direction corresponds to the direction of the geological structure and the direction of most of the straightness (Figures 2-5). Based on the variation in the value of the gravitational acceleration of the rock, the zone with a low gravitational acceleration value $(15-30 \mathrm{mGal})$, which is shown in blue, is interpreted as a type of sedimentary or pyroclastic rock. Meanwhile, zones with high gravitational acceleration values (41-60 mGal), which are shown in red, are interpreted as igneous or metamorphic types. Figure 7 shows that there are two areas that have contrasting anomalies that are interpreted as structures, namely in the southwest and northeast.

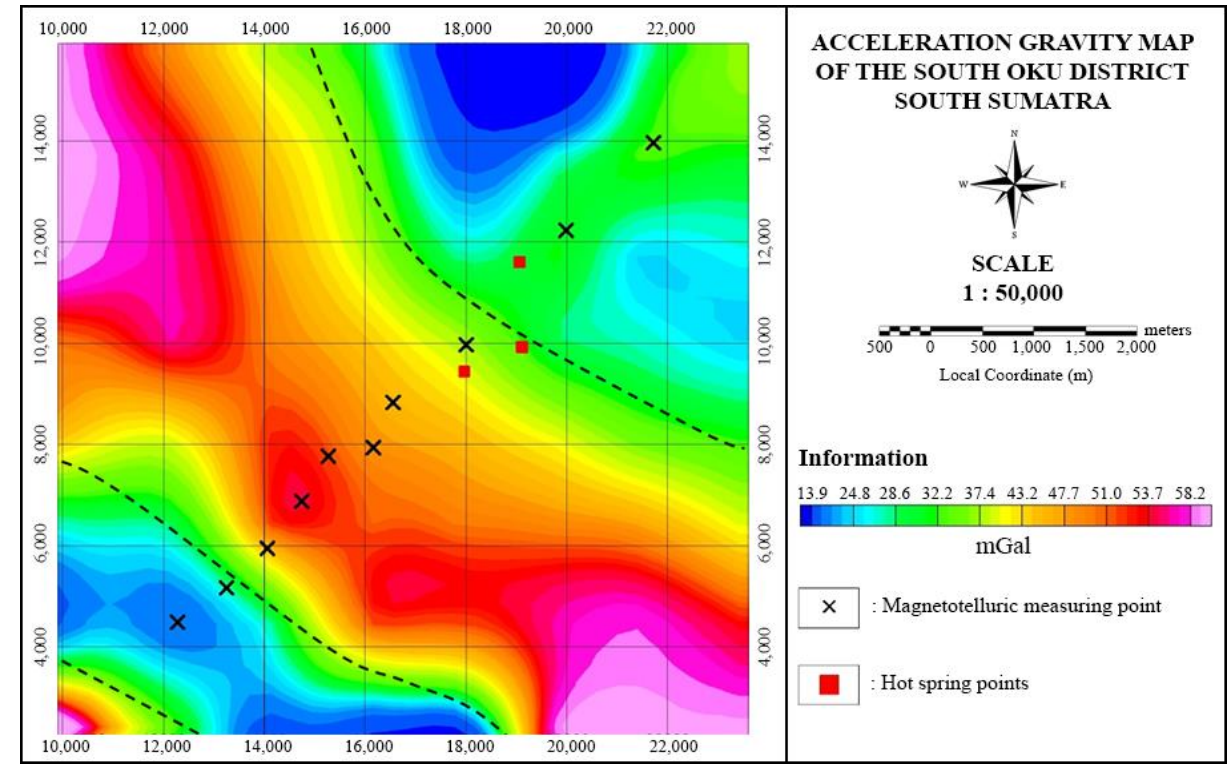

Figure 7. Acceleration gravity map. 


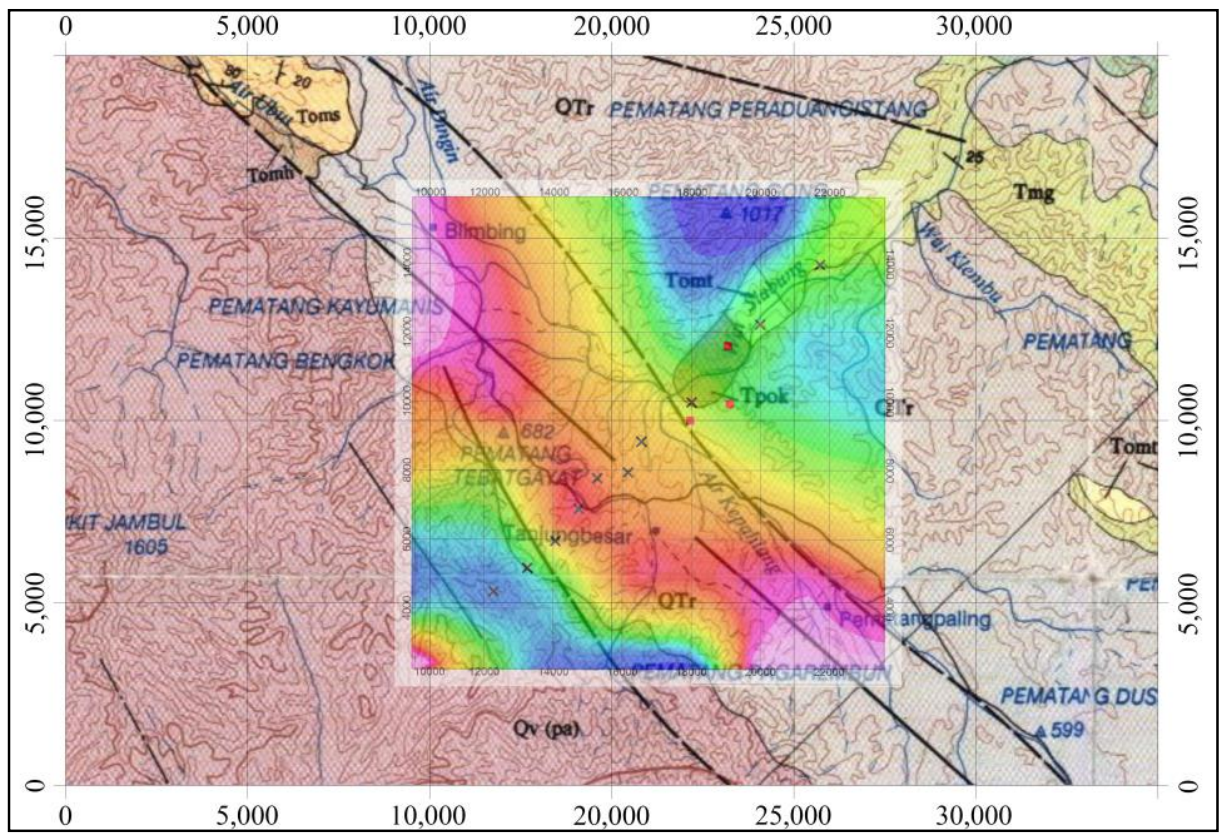

Figure 8. Overlay of the acceleration gravity map with the geological map.

The results overlay between the geological map sheet of Baturaja [7] and the gravity map (Figure 8), while the existence of geological structures based on gravity data is in accordance with the existence of structures on the geological map, which is located in the southwest and northeast of the study area in a northwest-southeast direction. The southwestern part of the geological map shows the existence of volcanic rock units $(\mathrm{Qv})$, but the gravity map shows a low anomaly. This is influenced by the presence of a structure so that the anomaly is lower than that of rocks that are not exposed to the structure. This difference can be seen at the southwestern end of the map, which has a high anomaly shown in red. The red zone is in the middle of the gravity map, which runs southwest-southeast. If correlated with the geological map, there are types of tuff rock (low density). However, if you look at the slice of the geological map, the zone contains igneous and metamorphic rocks underneath. The presence of these igneous and metamorphic rocks causes high anomalous values.

\subsection{Magnetotelluric Data (MT)}

The cross-section of the MT shows the variation in the resistivity value of the subsurface rock in the South OKU, South Sumatra, with a range of 5-2,000 $\Omega \mathrm{m}$ (Figure 9). The resistivity value of a medium is inversely proportional to the conductivity value. Zones with high resistivity values are interpreted in the presence of igneous or metamorphic rocks; meanwhile, zones with low resistivity values are interpreted in the presence of sedimentary or pyroclastic rocks. Both statements are based on the higher resistivity values of igneous and metamorphic rocks than sedimentary and pyroclastic rocks [11].

The MT path from left to right has a southwest-northeast direction and passes through three hot springs with a fluid temperature of $40-93{ }^{\circ} \mathrm{C}$ [2]. Hot springs are an indication of geothermal energy in the presence of fluid emerging from the earth's crust towards the earth's surface at temperatures above the normal temperature of the human body. The existence of geological structures based on gravity maps can be seen in more detail based on the MT section (Figure 9). Based on the cross-section of the MT, it can be interpreted that there are four structures controlling the hot spring fluid path, as shown by the black dotted line. There is a difference between the location of the structure based on the gravity map and the MT section, because the gravity data is lateral, while the MT data is lateral and vertical. This difference is influenced by the structure's depth location because the MT's cross section shows a structure that starts from between the points MT-01 and MT-02 continuously to between points MT-02 and MT-03. The gravity map shows the presence of a structure between the points MT-02 and MT-03.

At the top of the MT cross-section, a zone with a low resistivity value is shown in red $(<30 \Omega \mathrm{m})$. This low resistivity value is related to rocks that are conductive due to hydrothermal alteration and generally serve as an indicator of the geothermal prospect area, which is called clay cap/cap rock [20]. 


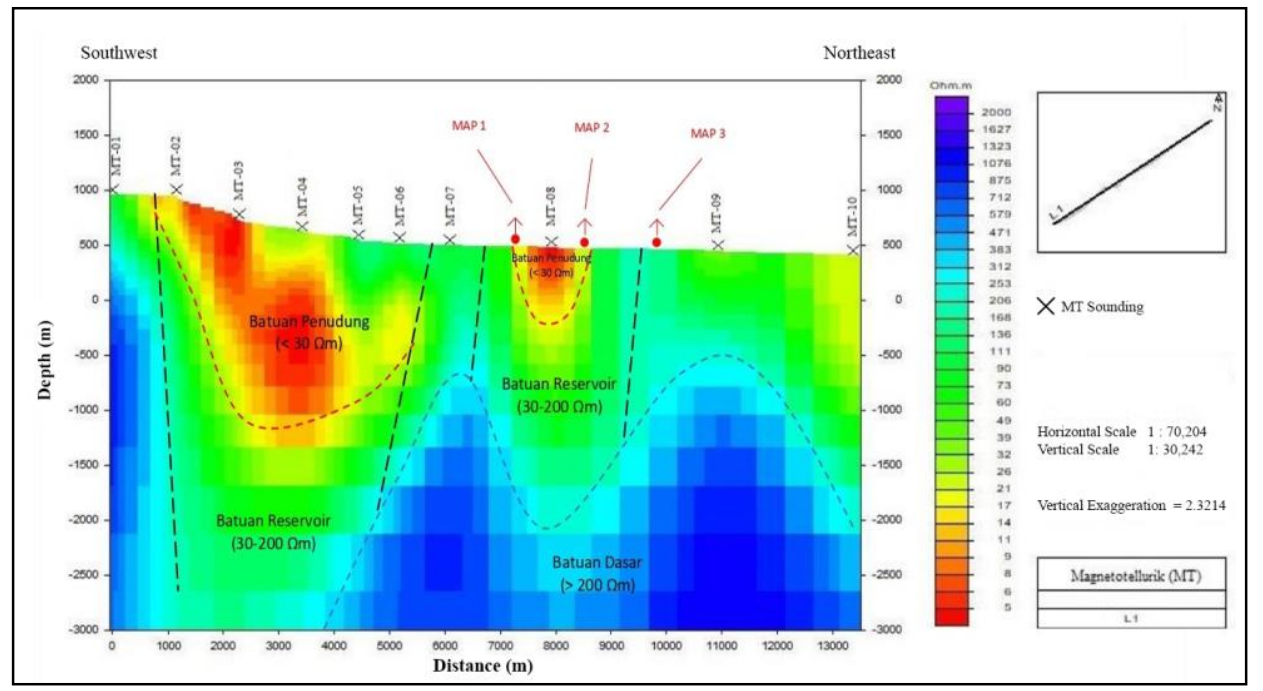

Figure 9. Cross-section of the MT.

Capstone layers (cap rock) are formed because of the hydrothermal process, which is a process that occurs as a result of the reaction between bedrock and the fluid produced from the presence of geothermal energy [21]. Based on the resistivity value, it is estimated that (clay cap) is a rock that has turned into an argillic alteration with clay grain size. The caprock functions as a fluid barrier so that it remains in the reservoir rock located below the caprock. The part below the red zone, you can see a green area with a higher resistivity value, namely $30-200 \Omega \mathrm{m}$. The green area is at a depth of (-500) to $(-2,500)$ meters, which is interpreted as reservoir rock in the form of clastic sedimentary rock. The blue zone with a high resistivity value $(>200 \Omega \mathrm{m})$, which lies at a depth of $>1,000 \mathrm{~m}$, is interpreted as the bedrock in the form of igneous rock. The igneous rock, like bedrock, indicates a heat source at the bottom.

It can be seen from the resistivity distribution pattern in the MT section; there is a resistivity contrast between MT-01 and MT-02 and between MT-06 and MT-07. The area is interpreted in the presence of a geological structure. The area between MT-08 and MT-09 is interpreted as having a geological structure due to the visible light blue zone, which continues to the surface. This structure is caused by bedrock, which forms two heights that may cause fractures at the top.

\section{Conclusion}

Remote sensing data with straightness density maps show permeable zones that can act as a path for geothermal fluids in the northeast, southeast, and southwest. The dominant direction of the straight line is northwest-southeast. The alignment direction corresponds to the direction of the geological structure based on geological maps and gravity maps. Based on the MT cross-section, there are cap rocks that have undergone argillic alteration with a resistivity of $<30 \Omega \mathrm{m}$. Right below the cap rock, there is reservoir rock at a depth of $(-500)$ to $(-2,500)$ meters in the form of clastic sedimentary rock with a resistivity of 30-200 $\Omega \mathrm{m}$. The part below the reservoir rock is the bedrock on the northeast side at a depth of $>1,000 \mathrm{~m}$ with a resistivity of $>200 \Omega \mathrm{m}$.

\section{Acknowledgment}

We wish to thank the Center for Coal and Geothermal Mineral Resources for their support in the form of data and guidance in MT processing.

\section{References}

[1] D. Y. W. S. Pambudi et al., "Delineasi Daerah Prospek Panas Bumi berdasarkan Kelurusan Citra Landsat dan Digital Elevation Model (DEM) Daerah Gunung Lawu Provinsi Jawa Tengah dan Jawa Timur," in Pros. Sem. Nas. Kebumian Ke-7, Yogyakarta: Universitas Gadjah Mada, pp. 438-446, 2014. 
[2] T. Rahadinata and A. Sugianto, "Survei Magnetotelurik dan TDEM Daerah Panas Bumi Way Selabung, Kabupaten Oku Selatan, Provinsi Sumatera Selatan," in Kolokium Kelompok Penyelidikan Bawah Permukaan Pusat Sumber Daya Geologi, Bandung: Pusat Sumber Daya Mineral Batubara dan Panas Bumi, 2014.

[3] A. Sugianto and Y. A. Muttaqin, "Survei Magnetotelurik Daerah Panas Bumi Way Selabung, Kabupaten Oku Selatan, Sumatera Selatan," in Pros. Hasil Kegiatan Pusat Sumber Daya Geologi, Bandung: Pusat Sumber Daya Mineral Batubara dan Panas Bumi, 2011.

[4] M. Soekarnoputri, "Panas Bumi," in Undang-Undang No. 27 Tahun 2003, Jakarta: Sekretariat Negara, 2003.

[5] W. B. Hamilton, Tectonics of the Indonesian Region, Washington: U.S. Government, 1979.

[6] A. Suherman et al., "Pemetaan dan Karakterisasi Potensi Energi Panas Bumi Sumatera Selatan dengan Penginderaan Jarak Jauh (INDERAJA)," in Proc. Applicable Innov. Eng. Sci. Res., Palembang: Universitas Sriwijaya, pp. 1138-1147, 2019.

[7] S. Gafoer, T. C. Amin, and R. Pardede, Peta Geologi Lembar Baturaja Sumatera, Bandung: Pusat Penelitian dan Pengembangan Geologi, 1993.

[8] Z. J. A. Saedi, "Lineament Extraction for Assessment of Groundwater Potential/West of Iraq," Euphrates J. Agriculture Sci., vol. 5, no. 1, pp. 54-63, 2013.

[9] M. M. Muhammad and A. H. Awdal, "Automatic Mapping of Lineaments using Shaded Relief Images Derived from Digital Elevation Model (DEM) in Erbil-Kurdistan Northeast Iraq," $A d v$. Natural Appl. Sci., vol. 6, no. 2, pp. 138-146, 2012.

[10] B. A. V. D. Pluijm and S. Marshak, Earth Structure an Introduction to Structural Geology and Tectonic, New York: W. W. Norton, 2004.

[11] W. M. Telford, L. P. Goldrat, and R. P. Sheriff, Applied Geophysics, 2nd ed., Cambridge: Cambridge University Pres, 1990.

[12] S. Ilmi, U. Harmokom, and S. Widada, "Interpretasi Bawah Permukaan Sistem Panas Bumi Diwak dan Derekan Berdasarkan Data Gravitasi", Youngster Phys. J., vol. 3, no. 2, pp. 165-170, 2014.

[13] J. A. Jacobs, R. D. Russel, and J. T. Wilson, Physics and Geology, New York: Mc Graw-Hill, 1974.

[14] K. Ushijima et al., "Magnetotelluric Soundings in the Takigami Geothermal Area Japan," in Proc. World Geotherm. Cong., Antalia: International Geothermal Association, 2005.

[15] T. V. S. Kadir, "Metode Magnetotelurik (MT) untuk Eksplorasi Panas Bumi Daerah Lili, Sulawesi Barat dengan Data Pendukung Metode Gravitasi," S.Si. thesis, Physics, Faculty of Mathematics and Natural Sciences, Universitas Indonesia, Depok, 2011.

[16] H. Grandis, "An Alternative Algorithm for One-Dimensional Magnetotelluric Response Calculation," Comp. Geosci., vol. 25, no. 2, pp. 119-125, 1999.

[17] A. I. Hadi, K. S. Brotopuspito, and Wahyudi, "Pemodelan Sebaran Sistem Hidrotermal dan Identifikasi Jenis Batuannya dengan Metode CSAMT: Studi Kasus Gunung Api Ungaran," J. Fis. Flux, vol. 6, no. 1, pp. 40-49, 2009.

[18] E. Türkoglu et al., "Lithospheric Structure of the Arabia-Eurasia Collision Zone in Eastern Anatolia from Magnetotelluric Exploration Evidence for Widespread Weakening by Fluids," GEOLOGY, vol. 36, no. 8, pp. 619-622, 2008.

[19] H. R. Burger, A. F. Sheehan, and C. H. Jones, Introduction to Applied Geophysics Exploring the Shallow Subsurface, New York: W.W. Norton, 2004.

[20] D. D. Wardhana et al., "Pencitraan Tahanan Jenis Bawah Permukaan di Area Prospek Panas Bumi Gunung Slamet berdasarkan Data Magnetotelurik," RISET Geol. dan Pertambangan, vol. 27, no. 1, pp. 111-121, 2017.

[21] Saptaji, Teknik Panas Bumi, Bandung: Institut Teknologi Bandung, 2001. 